Gastroenterologia. 1943;68:I-IV

\title{
Contents, Vol. 68, 1943
}

\section{INDEX}

Berg, G., Vergleichende Untersuchungen über die Wir-kung echten Bohnenkaffees und eines

Kaffee-Er-satzmittels auf die Magenfunktion .... 182

Demote, M., Alimentation de guerre et maladies diges

tives. L'alimentation de guerre est-elle responsable

de 1 'aspect nouveau de la pathologie digestive? .

- vide Martin, E.

Deucher, W. G., Röntgenbefunde am Dünndarm bei ver-

schiedenen Formen akuter Enteritis .... 43

Grumbach, A., Serum-, Chemo- und Vakzinetherapie der

Colitis ulcerosa 21

Hämmerli, A., Die Behandlung der Colitis ulcerosa gravis mittels der spezifischen

Autovaccinetherapie und der typspezifischen Enterokokken-Serumtherapie . 36

Lòffler, H., Zur klinischen Abgrenzung der Hepatitis

epidemica von andern Hepatitisformen .

Ly \&gt; on, E., Swelling of the Parotid Gland and Diabetes

Mellitus 139

Markoff, N., Liegt eine Zunahme der Magendarmkrankheiten in der jetzigen Zeit vor? ..... 225

Martin, E. et Demole, M., Une manifestation de carence

alimentaire: l'oedème de famine 169

Montant, R., La Gastrectomie dans le traitement de $\Gamma \mathrm{ul}-$ cère. (A propos de 40 cas.) ...... 286

Owren, P., Throniboeytémie essentielle .... 148

Reimann, F., Das ,,anämische Fieber”. 1. Über die erhöh-

ten Körpertemperaturen bei der perniziösen Anämie 197

Schmid, E. A., Der vereinfachte pH-Aciditätstest. Eine praktisch-brauchbare Methode zur exakten Bestim-mung freier und gebundener Säure-Basen-Radicale in Aequivralenten (H- und $\mathrm{OH}-$ Ionen) auf differenzie-

rende und integrierende Art mit besonderer Berück-

sichtigung des Harns. Zugleich ein Beitrag zur

Grundlegung einer elementaren Diätetik. (2. Mittei-

lung.) 53

Schneiter, P., Biologie der Darmflora und ihre klinische

Bedeutung 5

Rudolf Stähelin †, 28. August 1875 bis 26. März 1943 . 1

Gesellschaftsberichte - Sociétés - Society Transactions 
Société Suisse de Gastro-Entérologie - Schweizerische Gesellschaft für Gastro-Enterologie. XIIme Session, 7 et 8 novembre 1942 - XII. Tagung, 7. und 8. November 1942 in Zurich

Referate - Abstracts - Analyses . 73, 158, 217, 304

Buchbesprechungen - Books Review - Livres Nou-

veaux $110,168,340$ 